\title{
An Analytical Study to Determine Whether All of the Services of Conventional Banking Permissible or Forbidden in Islam
}

\author{
Mohammad Tanvir Islam ${ }^{1, ~ *, ~ M u h a m m a d ~ S h a f i u d d i n ~}{ }^{2, ~ *}$ \\ ${ }^{1}$ Capital Law Chamber, Dhaka, Bangladesh \\ ${ }^{2}$ Centre for Higher Studies and Research, Bangladesh University of Professionals, Dhaka, Bangladesh
}

Email address:

advtanvir5@gmail.com (M. T. Islam),mshafibd@outlook.com (M. Shafiuddin)

\section{To cite this article:}

Mohammad Tanvir Islam, Muhammad Shafiuddin. An Analytical Study to Determine Whether All of the Services of Conventional Banking Permissible or Forbidden in Islam. International Journal of Finance and Banking Research. Vol. 6, No. 4, 2020, pp. 83-89.

doi: 10.11648/j.jifbr.20200604.14

Received: June 22, 2020; Accepted: July 20, 2020; Published: September 10, 2020

\begin{abstract}
This Study shows the misconception of innocent Muslims on about "Are the service of conventional banking fully Haraam for the Muslim? This study is conducted the widespread misconception in innocent Muslim minds that everything associated with banking within the conventional system is prohibited in Islam. This probably stems from a lack of understanding and genuine desire of common Muslims to stay away from even remotely prohibitive income. Since this assumption of blanket prohibition is erroneous. In fact, there are clear guidelines in Islamic law and Islamic Sharia law [1]. This paper analyzes which services, functions and products have been Prohibited by Islamic law and Shariah and which services, functions and products have been allowed to be accepted subject to certain condition, There are many permissible (halal) functions that conventional banking institutions perform and make substantial profits from. In my view, Muslims may engage in such functions in the form of customers, employees, investors or advisers and if you have no direct involvement in any riba transaction, then it's fine to work there.
\end{abstract}

Keywords: Halal \& Non-Halal Product, Service and Faction, Qualitative Techniques

\section{Introduction}

The major contribution of this paper is that it is the first contextual comparative study examining the Halal \& nonhalal products, service \& function of Islamic Bank (PSFIB) and conventional Bank (CBs) employing the Servperf instead of the Servqual in Banlgadesh within the last 20 years. With the rapid expansion of information technology and the improvement of the Internet, the current economic activities have become more inter-mutual and dependable on the bank. Hence $60 \%$ of our financial activities like withdrawing and depositing money, buying and selling anything and most of government transaction, all transactions of studying in the country and abroad, issuing solvency certificate, paying school tuition fee and medical services, Import \& Export transaction are gone under bank management.

From this point of view Bangladesh has mixed banking system comprising nationalized, private, and foreign commercial bank with two dimension of banking Conventional Banking systems and Islamic Banking Systems which are allowed by the Bangladesh Bank (BB) to provide Islamic banking \& conventional Banking products and services [2]. At present territory unit absolute 54, commercial bank institution whereas 9 foreign Banks at present working alongside of 45, nearby business bank in our country [3].

As per the interior and Islamic Economics Division, Research Department, Bangladesh at the end of September 2016, 8-full-flaedged Islamic banks were working with 1,006 branches out of total 9,515 expanded in the financial business started their excursion to alleviate money related interest of muslim ummah. What's more, 20 Islamic financial parts of 9 ordinary business banks, and 25 Islamic financial windows of 7-regular business bank were then offering Islamic financial Service in Bangladesh.

Provided that Bangladesh Bank Annual Report 2018, 95\% of the banking needs of the general public are met by 
banking services of Sonali Bank Ltd (SBL), Janata Bank Ltd (JBL), Rupali Bank Ltd, Bangladesh Krishsi Bank Ltd and Bangladesh Development Bank Ltd (BDBL) that are unit the state own commercial bank of the country and followed within the conventional banking system. So that, there is no way to get all your services here as you wish, even if you don't have the mentality in Conventional Banking, you have to go to Conventional Bank to meet your necessities. Besides, if you are an employee, you will need to take help from a bank to raise your monthly salary or to pay electricity, gas, or any utility bill of your house. Since Islam is a complete way of life where the list of halal is much bigger than haram, Islam does not randomly forbid any work. Again, Islam has sometimes recognized the haram thing as halal, subject to certain conditions.

\section{Literature Review}

Beside out of 161 million population of Bangladesh, about $89 \%$ of them are Muslim, followed by $10.7 \%$ are Hindus and $0.6 \%$ are Buddhists and $0.4 \%$ is Christians. Therefore, Islamic Banking is crying need for the Bangladeshi population. In this regard, A conceptual model of perceived service quality was introduced by Md Abu Saleh et al. (2016) where he analyze perceptions of service quality and service image of Islamic banks may differ from those of conventional banks [4]. In this study they also highlight how Islamic banking practices differ from those of conventional banking in terms of service quality and image-related factors. Later on, In 2015, (Deasy Wulandaria et al) focus on customer decision-making in terms of perception of the differences in the quality of services between Islamic and conventional banking and In another study [5]., Muhammad Hanif (2014) point out the perceptional issues by identifying the similarities and differences in Islamic and conventional banking by addressing Islamic banking is not a mere copy of conventional practices rather major differences exist within the operations of Islamic Financial Institutions (IFIs) as compared with conventional banking [6] and during this regard an identical studies have done by Md. Abdul Awwal Sarker where he describe the performance, problem \& prospects of Islamic Banking in Bangladesh, on this studies he mentioned that Islamic banks cannot operate with its full efficiency level if it operates under a conventional banking framework, their efficiency goes down at a number of dimensions [7].

Basically, Works which were earlier confined to theoretical foundations of Islamic economic system, prohibition of riba, collection of zakat, critique of capitalism diversified to cover topics like sustainable growth, poverty reduction, awqaf, political economics of the role of government, redistribution of income, Functional Service Quality Satisfaction of Islamic and Conventional Credit Card Users in different countries and comparative study of conventional and Islamic Banks. But Scant attention was given to this field in early days when writings dealing with Islamic economics were limited to theological works on prohibition of product, service and function of Conventional Banks and some similar topics [8].
From 2000-2020, in Bangladesh no research has been done on analyzing which products, services and functions of Conventional Banking are Haram. This probably is the first comprehensive attempt to encapsulate details about Haraam product, service and function of Conventional Banks in Bangladesh.

\section{An Overview over Permissible and Non Permissible Product \& Service of Conventional Bank and Islamic Bank}

\subsection{Concept of Islamic and Conventional Banking}

Implementation of sharia principle in banking system using the principle of profit sharing instead of interest as applied in conventional banks. Islamic bank conducted its activities based on the Qur'an and the Hadith which is the foundation of Islam and by its unique characteristic it gives some ownership rights to customers. The principles of Islamic economic system is making a financial atmosphere between partners, lenders and borrowers (Yudistira, 2003) with the aim to accomplish the education of Holy Qur'an as contrastive to gathering financial gain on financial assets. Standards of Islamic Law are created in accordance with Shariah \& all dealings of Islamic system of finance governed by Shariah and Fiqah. Regular banks offer loaning offices to their customers to satisfy their money necessity based on credit contracts where the connection between the Bank and customer is that of money lender and borrower separately [9]. What's more, time esteem is the reason for charging enthusiasm on capital and Intrigue is charged even in the event that, the association endures misfortunes. There is no concept of sharing loss in conventional banking.

\subsection{Products, Services of Conventional Banking}

All commercial Bank performs the following functions that a bank is expected to perform which has vision to deliver service excellence through providing existing \& Innovative products in cost \& time-efficient manner, to its customer to offering the including services in the following categories: 1 . Account Opening (On opening Current, Saving \& Student Account). 2. Deposit the Money in the name of Savings \& Current Accounts for Short \& Long terms, 3. Provide a Loan in the form of SME Loan, SME installment base loan, Education loan, House loan, Car loan ei. 4. SMS and Internet Banking for giving information on about balance inquiry, fund transfer Utility bill payment, Statement generation, 5. Learning Center which helps one to...... Provide Debit and Credit \& Master Card, which provide you Various Service like (27 $\times 7$ Service), Discount Partner in the name of (EMI Partner, Discount Partner) on some partner company it maybe....... 6. Utility bill collection Service (By using this service anyone can pay his Telephone, Gas or Current or Internet or Cable network bill easily), 7. Revenue collection Service, Lend Registration fees collection service, Mobile Banking (This is banking Service where one can get some 
limited special banking service like transfer of money, The other name of Agent banking service is called Mobile Banking, namely Bikas, U-Pay, U-cash, Rocket and Sure Cash), 8. ATM Service (Where anyone can withdraw his money any time) 9. Locker Service (Where anyone can save his valuable thinks by pied) 10. Remittance Sending and Receiving service (By helping his service a man who lives in a foreign country he can send money for his family), 11. Agent Banking, Foreign Exchange, (Where you can get changes in your foreign currency like US Dollar, Soudian Real, and U.S.A Money easily, 12. VIP Banking Service, Where some bank offers a thoughtful bouquet of exclusive service, benefits and banking service to this valued and special customer like booking hotel in abroad, airport meet \& greet service, use the Airport Bolaka Lounge, 13."The Banking Jobs" section is designed to keep updated with latest banking jobs and career opportunities, 14. Bank Solvency Certificate (This Certificate need when any student or person have to show his capacity of financial status), 15. Collecting Student tuition fees, Payment of Government Salary

\subsection{Products, Services of Islamic Banking}

Islamic Shariah Based Bank has must not be exclusively benefit oriented, rather it must target advancing Islamic standards and qualities just as ensuring the necessities of Islamic culture all in all regularly the Muslim people group who needs to lead his life in the rule of Shariah and Islam. Basically Islamic Bank has the mission to decide and keep up the popular financial methods, to make guarantee sufficiency and advancement of the monetary framework bolstered Islamic standards. Islamic Bank Offer the accompanying administrations through the accompanying tasks

1. General Banking Service, 2. Internet or Online Banking Service, 3. Investment Service, 4. Foreign Exchange Business Service 5. Foreign Exchange Remittance service 6. Deposit Service 7. SMS Service 8. ATM Service 9. Cash Waqfa Deposit Service 10. Bill Purchase, 11. Khimah Debit and Credit Card Service \& Hajj Card Service 12. SWIFT Service 12. Tasdir Service, 13. Locker Service 14. Utility Bill Payment Service 15. Murabaha Notice serving Service [10].

\subsection{General Banking Service Under Islamic Bank}

In the General Banking sector also provide the mentioned bellow service Al-Wadeah Accounts Mudaraba Accounts AlWadeah Accounts Islami Bank operates Al-wadeah's Current Account on the principles of Al-wadeah. Moradabad Accounts From the attitude of those Accounts the Bank is 'Mudarib' and customers are 'Shahib Al-Mal'. In the interest of contributors, the Bank puts away their saved cash and appropriates least $65 \%$ of speculation pay earned through the sending of Mudaraba assets among Mudaraba investors [10].

\subsection{Islamic Banking Investment Mode}

The special feature of the Investment Policy of the Islamic Bank is to invest on the based on a profit-loss sharing system following tenets and principles of Islamic Shari'ah.
Following modes are used for investment:

Bia Mode:

1. Bia-Murabaha, 2. Bia-Muajjal, 3. Bai-Istijar, 4. Bai Salam, 5. Bai-As-Sarf, 6. Istisna,

Sahre Mode Ijara Mode

1. Murabaha 2. Musharaka 1. Mode of Hire Purchase Under Shirkatul Melk \& Welfare inv

Schemes [10].

\subsection{Welfare Oriented Investment Schemes}

i) House Hold Investment Scheme ii) Investment Scheme for Doctors (ISD) iii) Transport Investment Scheme (TIS) iv) Car Investment Scheme (CIS) v) Small Business Investment Scheme (SBIS) vi) Micro Industries Investment Scheme (MIIS) vii) Agricultural Implement Investment Scheme (AIIS) viii) Real Estate Investment Program (REIP), viiii) Real Estate Investment (Commercial \& Working Capital), $\mathrm{x}$ ) Agricultural Investment of IBBL, xi) NRB (Non Resident Bangladeshi) Entrepreneurs Investment Scheme (NEIS), xii) Women Entrepreneurs Investment Scheme (WEIS), xiii) Rural Development Scheme, xiv) NRB (Non Resident Bangladeshi Entrepreneurs Service xv) Remittance Card, xvi) Investment Scheme for Foreign Expatiate, SME Service xvii) Foreign Exchange business Service [10].

\subsection{Similarities and Differences of Islamic \& Conventional Bank in Terms of (SPF)}

Islamic Financial Institutions (IFIs) operate within the equivalent society where conventional banks do and perform all those functions which are expected from a financial organisation. IFIs assist business world by providing all the services required to accelerate the economy smoothly, however, the philosophy and operations are different. Any economic system is predicted to help in running the economy by providing the subsequent services grouped in two headings. First; Savings mobilization from savers to entrepreneurs and Second; Provision of general utility services as well as transfer of funds, facilitation in international trades, consultancy services, duty of valuables, and other service for a fee. There is no obstruction on provision of such services by IFIs except the service is against Shari'a [6]. However there exists distinction in mechanism of funds mobilization from savers to entrepreneurs as stated following. Savings mobilization consists of two phases' i.e. accretive deposits and enhance financing and investments.

\subsection{Research Questions}

1) Working in a riba-based bank without directly dealing with riba and depositing money in such a bank is halal ?

2) Is it permissible to open current accounts in riba-based banks to make things easier for customers?

3) What is the ruling on credit cards (visa card) from Islamic banks, knowing that they are free of interest? Even if one doesn't pay at the end of the permitted time. They only take yearly fixed fees for this service 
4) Ruling on receiving monthly salary via a riba-based bank is Permissible or not

5) Ruling on paying tuition fees, paying utility bill and discounts offered by the bank when loading a debit/credit card

\section{Misconception, Permissible, Non- Permissible Service \& Function of Conventional Banking Regarding the Research Questions}

\subsection{Misconception of Banking}

Numerous Pundits and spectators use terms, for example, Haram or Prohibited dreadfully effectively to portray some monetary and business structures. There are three reasons behind this

1. The view that in Shariah the Forbidden is the majority while the permissible is the minority or perhaps some regard this as more pious.

2. The lack of knowledge of what constitutions a Forbidden structure. This is simply lack of awareness of the basics of Fiqh-Al-Mu'amalat.

3. A certain unease relation to the similarities between some conventional products and Islamic Structure.

Because of absence of legitimate information on Islam somebody rearwards paper Money as illegal, somebody view the utilization of LIBOR as forbidden, while others insist that even having a bank is against the spirit of Shariah. Yet others regards a margin on a Deferred payment sale as akin to Riba, some view any guarantee provided in a transaction as forbidden, and do not know you can transfer debt. Actually none of these are forbidden. But it is very important to note that there is condition for ensuring such acts are Shariahcompliant, But People view the word "forbidden" as a better default until proven otherwise. They regard it as a more prudent and perhaps more pious. Haram may be a very big word and will be used only with serious knowledge, because it is as equally wrong to allow what's forbidden, because it is to forbid what is permissible [11].

Scholars were always hesitant to forbid until they found clear proof. It is important for people to know that the principal of commercial services in Shariah permissibility unless there is a reason to forbid. This is a fundamental principal for saying any things fo permissible or not. A great Scholar Ibn Taymiyyah (1263-1328 A. D) who stated the following in the Book of Contract

"Everything that is of benefit to the people, and has not been forbidden by Allah or his Messenger is Halal and no one has the right of forbid it" The basis of all contract is permissibility, except that which has been forbidden by Allah or his Messenger and Allah has not forbidden any contract which is of benefit to people unless it contain an overwhelming corruption"

\subsection{Some Permissible Product, Service \& Contract Under Islamic Principal of Banking}

Islamic Product, Service \& finance in general are ought to be founded on Islamic contracs (aqad i.e a commitment between two partise. While conducting Islamic banking activities, a client needs to execute some concurrence with his bank, The process by which customers and banks mutually complete their activities is supported by Islam if they comply with Islamic Sharia law and at that point these are halal for that client, Shairah compliant finance has its own product, service and contract which differ from conventional banking. Some of this product, service that Include Mudharabah (profit \& loss Sharing), Wahiah (Safekeeping) Musharakah (joint venture), Murabaha (cost plus finance) Ijara (leasing) Takaful (Islamic insrurance) and Shukuk (Islamic bonds). Provided in accordance with the Shariah principal, some contract are permissible that include Wakalah (In this contract the principal appoints a representative or agent or wakil in favor of him to perform some specific function including selling and buying, lending and borrowing, guarantee, gifting, litigation and making payments), The next is Hawala, (Hawala meaning "transfer" or "trust" In the conventional banking method transferring remittance to one geographical area to another it is used. Later on, Islamic scholars say that since electronic wire transfers have not been found in violation of sharia). And most important one is Kafala, Kafala means "surety" or "guaranty" in conventional finance. A third party accepts an existing obligation and becomes liable for fulfilling someone's liability. And last one is Rahn, which means collateral or pledge contract is property pledged against an obligation. Normally a Rahn contract is mead to secure a financial liability. [12].

\subsection{Non-permissible Function of Islamic Banking}

The rules for the administration of Islamic banks are clear, this Islamic law and Fiqh Al Muamalat has given a few rules to the financial framework. Finally a standard translation of Law and guide by Islamic financial aspects the contemporary development of Islamic Banking and finance prohibit a variety of activities such as any type of increasing, paying or charging interest is considered as Riba and hence prohibited, similarly Islam does not allow the business that involves haraam things These include things like as selling alcohol or pork, or producing media like as gossip columns or pornography. Whereas some Scholars believe that Charging extra for late payment is permissible in Islam but but most of the Islamic scholars are against this opinion. So there is no chance of taking extra for late payment in the Islamic Banking system. Maisir, which means "gambling", is another aspect of the prohibition of Islamic finance. Which literally use to mean "speculation" in Islamic finance. In this term the owner of the goods has to depend on the occurrence of a predetermined. Uncertain event within the future is maisir and forbidden in Islamic finance. Moreover, Islam has also banned Gharar related activities Islamic finance supporters 
believe these involve excessive risk and should foster uncertainty and fraudulent behavior like as are found in derivative instruments employed by conventional banking And the last thing we will discuss is Engaging in transactions lacking "material finality" Islam has identified this type of transaction is also as haram [12].

\subsection{Some scholars' Opinions Regarding the Research Questions}

1. Query: Working in a riba-based bank without directly dealing with riba and depositing money in such a bank is halal?

Opinion: Your working in this bank is haraam, even if you are in a department which does not deal with riba-based transactions. It is important to notice that the "central bank" is that the head bank and dealing within the other departments complements the work of the sections that accustom to deal with riba; the bank is made from all the departments and every one institutions connected thereto are engaged in riba [13].

2. Query: Is it permissible to open current accounts in ribabased banks to make things easier for customers?

Opinion: There is no blame on you for opening current accounts, except interest, in riba-based banks, if your commercial needs dictate that you simply should have various accounts, so as to enable Customers to create transfers without undue hardship or difficulty, so as long as you are trying to withdraw these funds from these banks immediately. And Allah knows best.

End quote from Majmoo 'Fataawa Ibn Baaz (19/413).

Shaykh Ibn 'Uthaymeen (may Allah have mercy on him) said: If you would like to open an account during a ribabased bank, there is nothing wrong with it, but if you do not need to do so, then do not do it.

Undoubtedly the foremost prudent approach any one should not to open any account in the least any riba-based bank, except in cases necessarily. One of the requirements that make it permissible to try to that is necessity to save one's money, or if an individual may be a businessman and it will be detrimental to his commercial interests if he does not have any accounts in conventional banks, or his salary is deposited in such a bank and he cannot access it except by opening an account therein bank - and other considerable needs. A number of trustworthy Islamic scholars have stated that a concession is granted allowing that in the case of need [13].

3. Query: What is the ruling on credit cards (visa card) from Islamic banks, knowing that they are free of interest? Even if one doesn't pay at the finish of the permitted time. They only take yearly fixed fees for this service

Opinion: It is permissible to use credit cards that are free from things that are forbidden in sharee'ah, such as charging interest for late payments, or charging a percentage of the cash withdrawn, because that comes under the heading of riba which is haraam. But if the bank charges a set fee when issuing or renewing the cardboard as a fee for the services offered, and covering only the value of these services, there is nothing wrong with that.
The Islamic Fiqh Council has issued a press release - no. $108(2 / 12)$ - concerning non-covered credit cards (i.e., a card covered by money pre-deposited within the card account), and therefore the ruling on the fees charged by the banks [13].

4. Query: Ruling on receiving monthly salary via a ribabased bank is Permissible or not.

Opinion: Among the cases necessarily that exist nowadays is what some countries and public and private institutions do, where they provide their employees their salaries and dues via riba-based banks. This action is haraam for these parties, because it strengthens the position of those banks, but there is no sin on the employee if he receives his monthly salary vide through those riba-based banks, but that is subject to certain conditions:

1. That the employee cannot find any other way except from that riba-based bank. If he can receive his salary directly from his employer or through an Islamic bank, then he has no excuse.

2. That he should not leave a part of his salary thereupon riba-based bank, otherwise he are going to be supporting them.

The solution for the one who has no choice but to use those banks is to open a current account and have his salary transferred thereto. It is acknowledged to all that current accounts are less serious than savings accounts, as current accounts are readily accessible and therefore the bank cannot make use of those funds.

The scholars of the Standing Committee said:

There is nothing wrong with taking salaries that are paid via the bank, because you are taking it reciprocally for your work for somebody aside from the bank. But that is subject to the condition that you simply do not leave it within the bank after it has been transferred to you due to the interest. End quote.

Shaykh 'Abd al-'Azeez ibn Baaz, Shaykh Saalih alFawzaan, Shaykh 'Abd al-'Azeez Aal al-Shaykh, Shaykh 'Abd-Allaah ibn Ghadyaan, Shaykh Bakr Abu Zayd.

Fataawa al-Lajnah al-Daa'imah (13/288, 289).

Shaykh Muhammad ibn Saalih al-'Uthaymeen (may Allaah have mercy on him) said:

There are some organizations, companies and legal entities, who make their employees open bank accounts so as to transfer their salaries to the bank. If any one cannot receive his salary except by this implies, there is nothing wrong with it, and he may open an account, but he should not open an account with this bank by paying his own money, i.e., he should not put a penny of his own money in it, but with reference to receiving his salary through this means, there is nothing wrong with it. End quote [13].

5. Query: Ruling on paying tuition fees, paying utility bill and discounts offered by the bank when loading a debit/credit card.

Opinion:

Firstly: It is permissible to pay tuition fees, utility bill useing a Visa card that is not loaded if the following reservations are avoided:

1. Stipulation of interest or a penalty within the event 
lately payment;

2. Charging a fee for issuing the unloaded card that is greater than the actual costs involved;

3. Deducting a percentage for withdrawal when the Visa card is not loaded; it is permissible to charge the actual cost only, and anything more than that comes under the heading of riba;

4. To pay tuition fees, utility bill buying gold, silver or currencies with an unloaded credit card.

A statement to this effect has been issued by the Islamic Fiqh Council. With regard to loaded or prepaid credit/debit cards, there is nothing wrong with using them, even if the bank charges a fee for issuing them or for making withdrawals with them that is greater than the actual costs, because what the bank charges in this case is not in return for the loan - because there is no loan in the first place - rather it is imposed a fee in return for creating it possible to use the credit/debit card.

Secondly:

Loading the credit card account is to be understood as being like a loan from the client to the bank, which is like making a deposit in a current account in the bank.

In the statement of the International Islamic Fiqh Council no. $86(9 / 3)$ on the topic of making deposits in bank accounts, that was held during its ninth conference in Abu Dhabi in the United Arab Emirates 1-6 Dhu'l-Qa'dah 1415 AH/1-6 April 1995 CE, it says:

After studying the research papers submitted to the Council on the topic of making deposits in bank accounts, and after listening to the discussion that took place on this topic:

Deposits in current accounts, whether they are in Islamic banks or riba-based banks, are loans from a fiqhi point of view, as the bank will receive these deposits, so it is responsible for them and is required, in accordance with sharee'ah, to return that cash upon request. The fact that the bank (the borrower) is well off makes no difference to the ruling on the loan. End quote.

\section{Data Collection Mythology of the Study}

An empirical research approach has been applied to enrich the research fields. The Research is conducted to find out the Haraam Fuction of Conventional Banking system that make a negative impact of The Muslim community of the world. The study is based on both secondary and primary data. As a sample frame the study used to collect the information, guideline and opinion of Islamic Scholar and Also Fiqh council and so form the statement of the Islamic Principal

It consisting of both sources of data that is, secondary as well as primary

Primary data

1) Primary data includes the results of the questionnaires,

2) Observations at the bank functionaries,

3) Informal discussion with Islamic Scholar,
4) Opinion of Islamic Scholar's

5) Statement of World Islamic Fiquh Council

Secondary

1) Secondary sources of the data include; Shariah Compliance,

2) Non-permissible function of Islamic banking As per Islamic Principal

3) Permissible contract of Islamic banking.

4) Reports of Social Islami Bank, Islami Bank Bangladesh Ltd. Al Arafah Bank, UCB Bank Ltd, Sonali Bank, Janata Bank and some Articles on Islamic Banking in Newspaper, books, journals, and other publications, Internet web sites, SBP Reports.

\section{Decisions}

All the activities, services and products of Conventional Banking are more or less an equivalent, apart from transaction mode and investment policy. Basically there is no service distinction between conventional and Islamic banking. It is only due to the strategy of providing services in Conventional Banking and the method of counting their interest that it becomes haram and sometimes halal. Basically with all the activities of charging interest or impose interest in return for any work or engaging in any business which is related to any matter in an uncertain future and any business whose profit usually comes from selling intoxicants, playing music and engaging in obscene activities like pornography. Islam forbids the involvement of such businesses where excessive interest is charged on the debtor and the business is run through lies or persuasion. Islam does impose restrictions on the activities related to interest but does not directly forbid other services where interest is not involved and therefore [14-15]. The issues of General Service and General Utility Services in Convention are completely haram. No such prohibition has been found in the Islamic Principal's review of this matter. Moreover, Islamic scholars and the Islamic Fiqh Council, have not directly declared the General Services and General Utility Services as Haram. Moreover, when a Muslim customer does not get the required service from Islami Bank or if Islami Bank does not provide that service, then Subject to certain Situation a customer can avail that service from any bank, whether it is Conventional or Islamic Bank. However, in this case, the Islamic scholars have instructed him to take care that it is not an interest-based transaction and does not violate Islamic Sharia [16].

\section{References}

[1] Durrani, D. M. (Feb 16, 2014). IS CONVENTIONAL BANKING ALL BAD? islamiceconomist.com.

[2] Ahmad, F. (2020). Islamic Banks vs. Conventional Banks in Bangladesh: A Comparative Study Based on its Efficiency in Operation. International Journal of Islamic Banking and Finance Research, 29-37. 
[3] BanksBD.org. (2020). Retrieved July 17, 2020, from www.banksbd.org: www.banksbd.org.

[4] Saleh, M. A., Quazi, A., Keating, B. W., \& Gaur, S. S. (2017). Quality and image of banking services: a comparative study of conventional and Islamic banks. International Journal of Bank Marketing, 35 (6), 878-902.

[5] Ari Subagio, D. W. (2015). Consumer Decision Making in Conventional Banks and Islamic Bank based on Quality of Service Perception. Procedia - Social and Behavioral Sciences 211, 471-475.

[6] Hanif, M. (2011). Differences and Similarities in Islamic and Conventional Banking. International Journal of Business and Social Science, 166-175.

[7] Md. Abdul Awwal Sarker. (n.d.). International Journal of Islamic Financial Services Vol. 1 No. 3.

[8] Shafiq, A. (2019). A Review of Journals \& Publishing Houses in the Field of Islamic Economics and Finance (Report No. 8). Istanbul: Research Center for Islamic Economics (IKAM).

[9] ALI, L. (September 2013). Comparison of Islamic and Conventional Banking. International Review of Management and Business Research, 837-846.
[10] page, I. B. (1983). Islami Bank Bangladesh Limitted. Retrieved July friday, 2020, from www.islamibankbd.com/prodServices/prodServices.php:www. islamibankbd.com.

[11] Alshubaily, N. (2018). Understanding What is Forbidden (Haram) in Financial Structures. Dubai, UAE: islamicmarkets.

[12] Wikipedia, the free encyclopedia. (n.d.). Retrieved July friday, 2020, from en.wikipedia.org/wiki/Islamic_finance_products,_services_an d_contracts\#Principles: en.wikipedia.org.

[13] Islam Question \& Answer. (1997), from islamqa.info:www.islamqa.info.

[14] Personal decisions of some Islamic Scholars Namely Mufti Mohammad Ullah.

[15] Personal decisions of Some Supreme Court Advocate, who work as Legal Advisor of Islamic Bank Bangladesh.

[16] Ministry of Finance (20092012) Activities of Banks and financial Institution. Government of People republic of Bangladesh, Retrieved. 